\title{
Impact of phosphorylation on thermal stability of proteins
}

Clément M. Potel ${ }^{1 \#}$, Nils Kurzawa ${ }^{1,2, \#}$, Isabelle Becher ${ }^{1, \#}$, Athanasios Typas ${ }^{1}$, André Mateus ${ }^{1, *}$, Mikhail M. Savitski ${ }^{1, *}$

\#These authors contributed equally

${ }^{1}$ European Molecular Biology Laboratory, Genome Biology Unit, Meyerhofstr. 1, 69117 Heidelberg, Germany.

${ }^{2}$ Candidate for joint PhD degree from EMBL and Heidelberg University, Faculty of Biosciences, 69120

Heidelberg, Germany

*Contacting authors:

Mikhail M. Savitski

Email: mikhail.savitski@embl.de

Phone: +496221 387-8560

André Mateus

Email: andre.mateus@embl.de

Phone: +49 $6221387-8825$

\section{Summary}

Reversible protein phosphorylation regulates virtually every cellular process and is arguably the most wellstudied post-translational modification. Still, less than $3 \%$ of the phosphorylation sites identified in humans have annotated functions. Functionally-relevant phosphorylation sites are known to trigger conformational changes to proteins and/or to regulate their interactions with other proteins, nucleic acids and small molecules - all of which can be reflected in the thermal stability of a protein. Thus, combining thermal proteome profiling (TPP) with phosphoproteomics (phospho-TPP) provides a way to assess the functional relevance of identified phosphorylation sites on a proteome-wide scale by comparing the melting behavior of a protein and its phosphorylated form(s). We performed phospho-TPP experiments in HeLa cells with an optimized protocol, and conclude that phosphorylation does affect protein thermal stability, but to a much lesser extent than previously reported. 


\section{Introduction}

Reversible protein phosphorylation regulates virtually every cellular process and is arguably the most wellstudied post-translational modification. ${ }^{1}$ Still, less than $3 \%$ of the phosphorylation sites identified in humans have annotated functions. ${ }^{2,3}$ Functionally-relevant phosphorylation sites are known to trigger conformational changes to proteins and/or to regulate their interactions with other proteins, nucleic acids and small molecules - all of which can be reflected in the thermal stability of a protein. ${ }^{4}$ Thus, combining thermal proteome profiling (TPP) ${ }^{5}$ with phosphoproteomics ${ }^{6}$ (phospho-TPP) provides a way to assess the functional relevance of identified phosphorylation sites on a proteome-wide scale by comparing the melting behavior of a protein and its phosphorylated form(s).

The first application of phospho-TPP was described by Azimi et al. ${ }^{7}$, though a systematic comparison between protein thermal stabilities and phosphorylated protein forms was not performed. Recently, Huang et al. ${ }^{8}$ investigated the effect of 2,883 phosphorylation sites on protein thermal stability, and reported significant changes in the melting behavior for 719 (25\%) of these sites (without multiple testing correction). Moreover, the correlation between the melting point of a protein and its phosphorylated form(s) was surprisingly low $\left(\mathrm{R}^{2}=0.18\right.$; Fig. 1A; Supplementary Fig. 1). This would imply that most phosphorylation events fundamentally reshape the thermal stability of proteins. While this constitutes an exciting hypothesis, we hereby show that this low correlation is likely technically- rather than biologicallydriven. Indeed, when assessing the reproducibility of the published protein melting point $\left(\mathrm{T}_{\mathrm{m}}\right)$ data, ${ }^{8}$ we found low correlations between replicates, both for the melting points of non-modified (average $\mathrm{R}^{2}$ of 0.43 between replicates) (Supplementary Fig. 2) and of phosphorylated proteins (average $\mathrm{R}^{2}$ of 0.22 ) (Supplementary Fig. 3) - despite the claims of high reproducibility of $\mathrm{T}_{\mathrm{m}}$ by the authors (see Supplementary discussion on ' $\mathrm{T}_{\mathrm{m}}$ estimate reproducibility'). After carefully re-evaluating their work, we identified multiple key points that contributed to this poor reproducibility and the unexpected high impact of phosphorylation on protein thermal stability (see Supplementary discussion). Therefore, we performed phospho-TPP experiments in HeLa cells with an optimized protocol (Supplementary Fig. 4), and conclude that phosphorylation does affect protein thermal stability, but to a much lesser extent than previously reported (Fig. 1A-B). ${ }^{8}$ This is reinforced by an accompanying analysis by an independent research group ${ }^{9}$.

\section{Results and Discussion}

Our phospho-TPP analytical strategy resembled the approach by Huang et al. ${ }^{8}$ (Supplementary Fig. 4), but with critical differences in that: i) we labeled peptides for quantification with tandem mass tags (TMT) prior to phosphopeptides enrichment to eliminate potential biases introduced by the individual phosphopeptide enrichment of the different temperatures and the separate labeling of non-modified and 
phosphopeptides; ii) we used two orthogonal chromatographic separations prior to mass spectrometry analysis to gain experimental depth and minimize TMT ratio compression arising from peptides coisolation; ${ }^{9}$ and iii) we implemented a robust data analysis approach including two data normalization steps and multiple testing correction (Supplementary table). In total, we identified 42,051 unique phosphopeptides across five biological replicates (Supplementary data 1-2). Notably, phosphopeptides constituted $98 \%$ of reliably identified peptides in the enriched samples - contrary to Huang et al. ${ }^{8}$, in which a reanalysis of their data yielded $61 \%$ of phosphopeptides (noted to be variable between replicates in an accompanying Matters Arising ${ }^{9}$ ). Our approach yielded high $\mathrm{T}_{\mathrm{m}}$ reproducibility between biological replicates of both non-modified (average $\mathrm{R}^{2}$ of 0.86; Supplementary Fig. 5) and phosphorylated proteins (average $\mathrm{R}^{2}$ of 0.78 ; Supplementary Fig. 6). Further, we compared the $\mathrm{T}_{\mathrm{m}}$ of non-modified proteins to previously published datasets ${ }^{10,11}$ (including from other cell lines and acquired in different laboratories; Supplementary Fig. 7), and observed substantially higher correlation with our dataset (average $\mathrm{R}^{2}$ of 0.75 ) than with Huang et al. ${ }^{8}$ (average $\mathrm{R}^{2}$ of 0.43 ).

With our approach, we could confidently compare the melting behavior of 7,864 unique phosphopeptides with their corresponding proteins (these represented cases for which we had data for the phophopeptide and the corresponding non-modified protein in at least three replicates, and a high quality melting curve; Supplementary data 3). In contrast to Huang et al. ${ }^{8}$ (Fig. 1A), we observed a good agreement between the $\mathrm{T}_{\mathrm{m}}$ of proteins and phosphorylated form $(\mathrm{s})\left(\mathrm{R}^{2}=0.65\right.$; Fig. 1B), with 129 phosphopeptides showing a statistically significant difference in their melting behavior compared to their respective proteins. These phosphorylation sites showed significantly higher predicted functional relevance ${ }^{12}(\mathrm{p}=0.0011$, Wilcoxon signed-rank test; Fig. 1C), suggesting that sites with altered thermal stability are likely to be biologically relevant. This was not the case for the significant sites annotated by Huang et al. ${ }^{8}(p=0.17$; Fig. 1C). Even though we identified significant differences in melting behavior of phosphorylation sites for some of the examples highlighted in Huang et al. ${ }^{8}$ (e.g., pSer58 of TPI1, which is thermally destabilized), these cases constitute the exception rather than the rule. This was further emphasized by the fact that from the 237 significant phosphosites identified in Huang et al. ${ }^{8}$ that were among our 7,864 high quality cases, the majority of them $(98.7 \%$; 234 sites) showed no significant change in melting behavior (Fig. 1B). Taken together, our study shows that the structural remodeling due to phosphorylation is not as widespread as previously reported, and that overall there is a good agreement between the melting behavior of proteins and phosphorylated proteoforms.

Despite the general concordance of melting behaviors of phosphorylated and non-phosphorylated forms of proteins, we observed a number of cases where phosphorylation significantly impacted the thermal stability of proteins (Fig. 1D-F). For example, phosphorylation on Tyr397 of the non-receptor tyrosine-protein 
kinase Lyn, which is involved in the regulation of immune response, hematopoiesis and response to DNA damage, ${ }^{13}$ led to a significant decrease in thermal stability of this protein $\left(\Delta \mathrm{T}_{\mathrm{m}}=-5.2{ }^{\circ} \mathrm{C}\right.$; Fig. 1D). Phosphorylation on this site within the activation loop of Lyn influences its activity by inducing a known conformational change that increases accessibility to the ATP binding pocket. ${ }^{13}$ Another interesting example are the phosphorylations on Thr19 and Ser22 of Lamin A, which led to a significant decrease of thermal stability $\left(\Delta \mathrm{T}_{\mathrm{m}}=-8.6^{\circ} \mathrm{C}\right.$; Fig. $\left.1 \mathrm{E}\right)$. Lamin $\mathrm{A}$ is a nuclear intermediate filament protein that regulates chromatin organization, replication and transcription through DNA and transcription factor binding, ${ }^{14}$ with phosphorylation of Thr19 and Ser22 being essential for its disassembly during mitosis. ${ }^{15}$ Finally, the calcium-regulated heat-stable protein CARHSP1 contains a cold-shock domain that binds RNA and singlestranded DNA, which stabilizes the tumor necrosis factor mRNA in processing bodies and exosomes. ${ }^{16}$ In accordance with the fact that a Ser41 phosphomimetic mutant decreases the affinity towards nucleic acids and abolishes protein localization in stress granules, ${ }^{17}$ we detected a significant decrease in protein thermal stability for the phosphorylated Ser41 proteoform $\left(\Delta \mathrm{T}_{\mathrm{m}}=-9.3{ }^{\circ} \mathrm{C}\right.$; Fig. $\left.1 \mathrm{~F}\right)$. In this case, phospho-TPP was able to resolve the thermal stability effect of Ser41 phosphorylation from that of adjacent phosphosites in the same phosphopeptide, for which melting behavior resembled that of the non-modified protein (Supplementary Fig. 8).

In conclusion, we present a strategy for performing and analyzing phospho-TPP experiments and provide a high quality dataset, which will serve as a resource for understanding the effects of phosphorylation on protein thermal stability. Phosphorylation sites which have a significant effect on protein thermal stability are more likely to be functionally relevant, by modulating protein conformation, localization, and protein interactions. 


\section{Acknowledgements}

This work was supported by the European Molecular Biology Laboratory. C.P. and A.M. were supported by a fellowship from the EMBL Interdisciplinary Postdoc (EI3POD) programme under Marie

Skłodowska-Curie Actions COFUND (grant number 664726). N.K. was supported by a fellowship of the

EMBL International $\mathrm{PhD}$ programme (EIPP).

\section{Competing interests}

The authors declare no competing interests.

\section{Author contributions}

C.P., I.B., A.M. performed the experimental work. N.K. performed the data analysis. All authors contributed to the interpretation of the data and writing of the manuscript. 


\section{References}

1 Cohen, P. The role of protein phosphorylation in human health and disease. The Sir Hans Krebs Medal Lecture. Eur J Biochem 268, 5001-5010, doi:10.1046/j.0014-2956.2001.02473.x (2001).

2 Hornbeck, P. V. et al. PhosphoSitePlus, 2014: mutations, PTMs and recalibrations. Nucleic Acids Res 43, D512-520, doi:10.1093/nar/gku1267 (2015).

3 Needham, E. J., Parker, B. L., Burykin, T., James, D. E. \& Humphrey, S. J. Illuminating the dark phosphoproteome. Sci Signal 12, doi:10.1126/scisignal.aau8645 (2019).

4 Mateus, A., Maatta, T. A. \& Savitski, M. M. Thermal proteome profiling: unbiased assessment of protein state through heat-induced stability changes. Proteome Sci 15, 13, doi:10.1186/s12953-0170122-4 (2016).

5 Savitski, M. M. et al. Tracking cancer drugs in living cells by thermal profiling of the proteome. Science 346, 1255784, doi:10.1126/science.1255784 (2014).

6 Riley, N. M. \& Coon, J. J. Phosphoproteomics in the Age of Rapid and Deep Proteome Profiling. Anal Chem 88, 74-94, doi:10.1021/acs.analchem.5b04123 (2016).

7 Azimi, A. et al. Targeting CDK2 overcomes melanoma resistance against BRAF and Hsp90 inhibitors. Mol Syst Biol 14, e7858, doi:10.15252/msb.20177858 (2018).

8 Huang, J. X. et al. High throughput discovery of functional protein modifications by Hotspot Thermal Profiling. Nature Methods, doi:10.1038/s41592-019-0499-3 (2019).

9 Smith, I. \& et al. Identification of phosphosites that alter protein thermal stability. (unpublished).

10 Tan, C. S. H. et al. Thermal proximity coaggregation for system-wide profiling of protein complex dynamics in cells. Science 359, 1170-1177, doi:10.1126/science.aan0346 (2018).

11 Becher, I. et al. Pervasive Protein Thermal Stability Variation during the Cell Cycle. Cell 173, 14951507 e1418, doi:10.1016/j.cell.2018.03.053 (2018).

12 Ochoa, D. et al. The functional landscape of the human phosphoproteome. Nature Biotechnology, doi:10.1038/s41587-019-0344-3 (2019).

13 Ingley, E. Functions of the Lyn tyrosine kinase in health and disease. Cell Commun Signal 10, 21, doi:10.1186/1478-811X-10-21 (2012).

14 Gruenbaum, Y. \& Foisner, R. Lamins: nuclear intermediate filament proteins with fundamental functions in nuclear mechanics and genome regulation. Annu Rev Biochem 84, 131-164, doi:10.1146/annurev-biochem-060614-034115 (2015).

15 Heald, R. \& McKeon, F. Mutations of phosphorylation sites in lamin A that prevent nuclear lamina disassembly in mitosis. Cell 61, 579-589, doi:10.1016/0092-8674(90)90470-y (1990).

16 Pfeiffer, J. R., McAvoy, B. L., Fecteau, R. E., Deleault, K. M. \& Brooks, S. A. CARHSP1 is required for effective tumor necrosis factor alpha mRNA stabilization and localizes to processing bodies and exosomes. Mol Cell Biol 31, 277-286, doi:10.1128/MCB.00775-10 (2011).

17 Hou, H. et al. Structure-functional analyses of CRHSP-24 plasticity and dynamics in oxidative stress response. J Biol Chem 286, 9623-9635, doi:10.1074/jbc.M110.177436 (2011). 

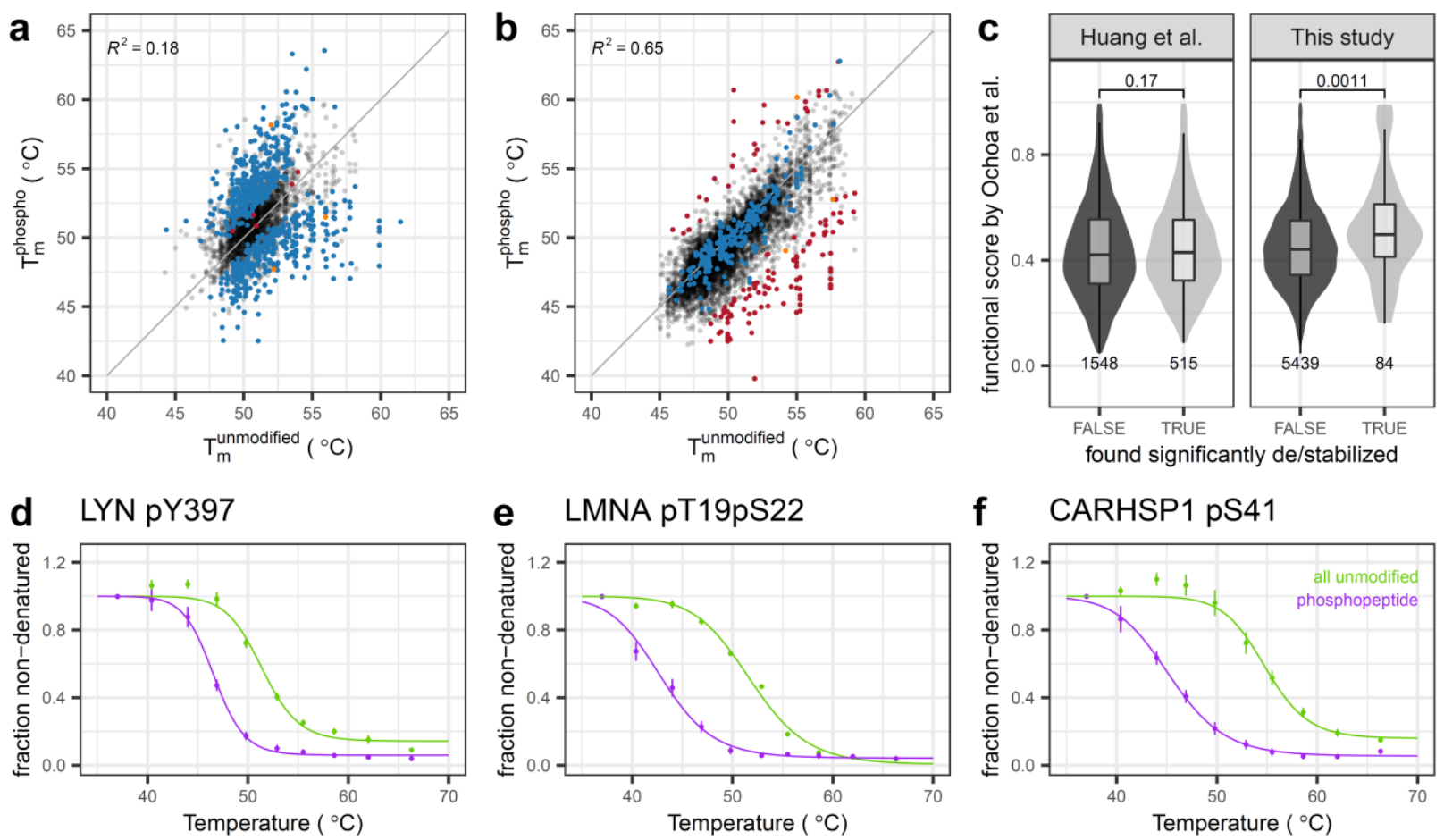

Fig. 1. Global impact of phosphorylation on thermal stability of proteins is less extensive than previously reported. (a-b) Comparison of non-modified and phosphorylated protein $T_{m}$ in (a) Huang et al. ${ }^{8}$ and this study (b). The grey line represents the identity line, points are colored according to: hits called significant by the original work (blue), hits found by this study (red) and overlapping hits between the two studies (orange). (c) Comparison of predicted functional importance of significant and nonsignificant phosphosites between the two studies (Wilcoxon signed-rank test) - the functional score aggregates multiple parameters for each phosphosite using machine learning and ranges from 0 to 1 , with a higher value representing a higher probability that the phosphosite has functional relevance ${ }^{12}$. Center line in box plots represents the median, bounds of the boxes are the $25^{\text {th }}$ and $75^{\text {th }}$ percentiles, and the whiskers correspond to the highest or lowest value, or if the lowest or highest value is an outlier (i.e., greater than 1.5-fold of the interquartile range), they correspond to 1.5 -fold of the interquartile range. (df) Examples of melting curves of significant hits found in this study. Error bars represent standard error of the mean. 
bioRxiv preprint doi: https://doi.org/10.1101/2020.01.14.903849; this version posted January 14,2020 . The copyright holder for this preprint (which was not certified by peer review) is the author/funder, who has granted bioRxiv a license to display the preprint in perpetuity. It is made available under aCC-BY-NC-ND 4.0 International license. 


\section{Supplementary information}

\section{Impact of phosphorylation on thermal stability of proteins}

\section{Contents}

Methods

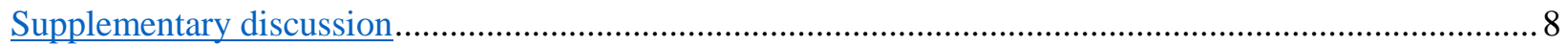

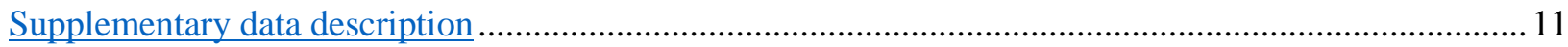

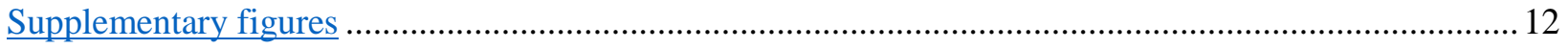

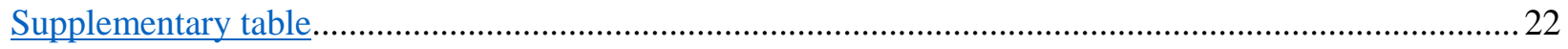

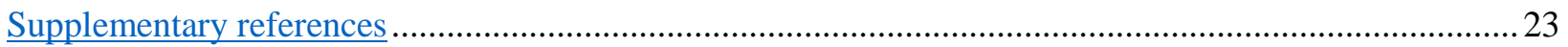




\section{Methods}

\section{Cell culture}

HeLa Kyoto cells were cultured at $37{ }^{\circ} \mathrm{C}, 5 \% \mathrm{CO}_{2}$, in DMEM including $1 \mathrm{mg} / \mathrm{ml}$ glucose, supplemented with $10 \%$ fetal bovine serum and $1 \mathrm{mM}$ glutamine.

\section{Thermal proteome profiling}

Thermal proteome profiling was performed as previously described..$^{1-3}$ Briefly, for each replicate ten $2 \times 10^{7}$ HeLaK aliquots were heated for 3 min to a range of temperatures (37.0-40.4-44.0-46.9-49.8-52.9-55.558.6-62.0-66.3 ${ }^{\circ} \mathrm{C}$ ). After another $3 \mathrm{~min}$ incubation at room temperature, cells were lysed for $1 \mathrm{~h}$ at $4{ }^{\circ} \mathrm{C}$ (lysis buffer: $0.8 \% \mathrm{NP}-40,1.5 \mathrm{mM} \mathrm{MgCl}_{2}, \mathrm{cOmplete}$ protease inhibitors, PhosStop, benzonase, $2 \mathrm{mM} \mathrm{NaF}$, $2 \mathrm{mM} \mathrm{Na} \mathrm{VO}_{4}, 2 \mathrm{mM} \mathrm{Na} \mathrm{O}_{2} \mathrm{P}_{7}$ in PBS). Heat-induced protein aggregates were removed by filter plates (Millipore, $0.45 \mu \mathrm{m}$ ) and the soluble fraction was used for protein concentration determination.

\section{Protein digestion and peptide labelling}

Approximately $300 \mu \mathrm{g}$ protein (determined for the lowest temperature) were diluted with sonication buffer (1\% sodium deoxycholate, $5 \mathrm{mM}$ tris(2-carboxyethyl)phosphine, $30 \mathrm{mM}$ chloroacetamide, $1 \mathrm{mM} \mathrm{MgCl}_{2}$, $1 \%$ benzonase) and sonicated in bioruptor for 15 cycles (30 s on/30 s off). Another incubation with $1 \%$ benzonase was performed for at least $30 \mathrm{~min}$ at room temperature, to remove nucleic acids, which are common contaminants of phosphopeptide enrichment. ${ }^{4}$

Proteins were digested according to a modified SP3 protocol. ${ }^{5,6}$ Briefly, protein samples were added to the bead suspension (Thermo Fisher Scientific-Sera-Mag Speed Beads, CAT\# 4515-2105-050250, 65152105-050250) in ethanol. After a 15 min incubation at room temperature with shaking, beads were washed four times with $70 \%$ ethanol. Next, proteins were digested overnight by adding $100 \mu \mathrm{l}$ of digest solution (30 mM chloroacetamide, $5 \mathrm{mM}$ TCEP, $1 \mu \mathrm{g} / \mu \mathrm{l}$ trypsin, in $100 \mathrm{mM}$ HEPES $\mathrm{pH}$ 8). Peptides then were eluted from the beads, dried under vacuum, reconstituted in $20 \mu \mathrm{l}$ of water, and labeled for 60 min at room temperature with $800 \mu \mathrm{g}$ of TMT10plex (Thermo Fisher Scientific) dissolved in $8 \mu \mathrm{l}$ of acetonitrile. The reaction was quenched with $8 \mu \mathrm{l}$ of $5 \%$ hydroxylamine, and experiments belonging to one TPP-TR replicate were combined. Samples were acidified with trifluoroacetic acid (TFA, final concentration of 1\%) and desalted with solid-phase extraction by loading the samples onto a Waters t-C18 SepPak 50 mg column, washing them twice with $1 \mathrm{ml}$ of $0.1 \%$ TFA, eluting them with $400 \mu \mathrm{l}$ of $50 \%$ acetonitrile acidified with $0.1 \%$ TFA, before lyophilisation. 


\section{Phosphopeptide enrichment}

The phosphopeptide enrichment was performed generally as previously described ${ }^{4}$. Briefly, lyophilized peptides were resuspended in buffer A (70\% ACN, 0.07\% TFA) and injected on a ProPac IMAC-10 column (Thermo Fisher Scientific, 4x50 mm) loaded with $\mathrm{Fe}^{3+}$ cations. Peptide loading was performed at a flow rate of $400 \mu \mathrm{L} / \mathrm{min}$ for 6 minutes using an Ultimate 3000 UHPLC liquid chromatography system (Thermo Fisher Scientific). After washing with $100 \%$ buffer A for 6 minutes at $1 \mathrm{ml} / \mathrm{min}$, phosphopeptides were eluted by switching to $50 \%$ buffer B (0.3\% ammonia) for 2 minutes, at a flow rate of $500 \mu \mathrm{l} / \mathrm{min}$. Both the non-bound and phosphopeptides fractions were collected before lyophilisation.

\section{High $\mathrm{pH}$ fractionation}

An aliquot (5\%) of the non-bound fraction from the phosphopeptide enrichment step was fractionated onto 29 fractions on a Phenomenex Gemini $3 \mu \mathrm{m} \mathrm{C18} 110 \AA 100 \mathrm{~mm}$ x 1 mm column under high pH conditions. ${ }^{5}$ This consisted of an 85 min gradient (mobile phase A: $20 \mathrm{mM}$ ammonium formate ( $\mathrm{pH} 10$ ) and mobile phase B: acetonitrile) at a $0.1 \mathrm{ml} / \mathrm{min}$ starting at $0 \% \mathrm{~B}$, followed by a linear increase to $35 \% \mathrm{~B}$ from $2 \mathrm{~min}$ to $60 \mathrm{~min}$, with a subsequent increase to $85 \% \mathrm{~B}$ from up to $62 \mathrm{~min}$ and holding this up to $68 \mathrm{~min}$, which was followed by a linear decrease to $0 \% \mathrm{~B}$ up to $70 \mathrm{~min}$, finishing with a hold at this level until the end of the run. Fractions were collected every two minutes from $12 \mathrm{~min}$ to $70 \mathrm{~min}$ and every $12^{\text {th }}$ fraction was pooled together.

Phosphopeptides were fractionated using in-house packed C18 microcolumns. To do so, gel loader tips were plugged with C18 resin (Affinisep AttractSPE C18 Disks) before packing with $1 \mathrm{mg}$ of C18 material (Dr Maisch, $5 \mu \mathrm{m}, 120 \AA$ A). Dried phosphopeptides were resuspended in $40 \mu \mathrm{L}$ buffer A (20 mM ammonium formate at $\mathrm{pH} 10$ ) before loading onto the microcolumn by centrifugation (loading speed $\approx 10 \mu \mathrm{l} / \mathrm{min}$ ) and wash with $10 \mu \mathrm{L}$ buffer A. Phosphopeptides were fractionated using a stepped gradient of acetonitrile consisting of sequential addition/elutions with $10 \mu \mathrm{l}$ of the following solutions: $1 \%, 3 \%, 5 \%, 7 \%, 9 \%, 11 \%$, $13 \%, 15 \%, 17 \%, 19 \%, 21 \%, 23 \%, 24 \%, 26 \%, 28 \%, 30 \%, 35 \%, 40 \%$ acetonitrile/buffer A (elution speed $\approx$ $10 \mu \mathrm{l} / \mathrm{min}$ ). The flow-through and wash were collected and correspond to the fraction FT, while elutions with $1 \%$ and $3 \%$ acetonitrile were pooled and correspond to fraction F0. The other elutions were pooled as follow: $\mathrm{F} 1=5 \%, 17 \%, 28 \%$; F2 = 7\%, 19\%, 30\%; F3 = 9\%, 21\%, 35\%; F4 = 11\%, 23\%, 40\%; F5 = 13\%, $24 \% ; \mathrm{F} 6=15 \%, 26 \%$.

\section{$\underline{\text { LC-MS/MS measurements }}$}

Peptides were separated using an UltiMate 3000 RSLCnano system (Thermo Fisher Scientific) equipped with a trapping cartridge (Precolumn; C18 PepMap 100, $5 \mu \mathrm{m}, 300 \mu \mathrm{m}$ i.d. $\times 5$ mm, $100 \AA$ A) and an analytical 
column (Waters nanoEase HSS C18 T3, $75 \mu \mathrm{m} \times 25 \mathrm{~cm}, 1.8 \mu \mathrm{m}, 100 \AA$ ). Solvent A was $0.1 \%$ formic acid in LC-MS grade water and solvent B was $0.1 \%$ formic acid in LC-MS grade acetonitrile. Peptides were loaded onto the trapping cartridge ( $30 \mu \mathrm{l} / \mathrm{min}$ of solvent A for $3 \mathrm{~min}$ ) and eluted with a constant flow of 300 $\mathrm{nl} / \mathrm{min}$ using a $120 \mathrm{~min}$ analysis time (with a 10-28\% B linear gradient, followed by an increase to $40 \% \mathrm{~B}$, and re-equilibration to initial conditions). The LC system was coupled to a Fusion Lumos Tribrid mass spectrometer (Thermo Fisher Scientific) operated in positive ion mode with a spray voltage of $2.2 \mathrm{kV}$ and capillary temperature of $275^{\circ} \mathrm{C}$. Full-scan MS spectra with a mass range of $375-1,500 \mathrm{~m} / \mathrm{z}$ were acquired in profile mode in the Orbitrap using a resolution of 120,000 (maximum injection time of $50 \mathrm{~ms}$ and automatic gain control (AGC) set to $4 \mathrm{e} 5$ charges). The mass spectrometer was operated in data dependent acquisition mode with a maximum duty cycle time of $3 \mathrm{~s}$. The most intense precursors with charge states 2-7 and a minimum intensity of 2e5 were selected for subsequent HCD fragmentation (isolation window of $0.7 \mathrm{~m} / \mathrm{z}$ and normalized collision energy of $36 \%$ ) with a 60 seconds dynamic exclusion window, and MS/MS spectra were acquired in profile mode with a resolution of 30,000 in the Orbitrap (maximum injection time of $94 \mathrm{~ms}$ and AGC target of 1e5 charges).

Phosphopeptide fractions were analyzed on the same LC-MS/MS system with a few differences listed below. Phosphopeptides were resuspended in a mixture of $50 \mathrm{mM}$ citric acid and $1 \%$ formic acid before loading, trapping and separation using a linear gradient from $8 \%$ to $25 \%$ buffer B, followed by an increase to $40 \%$ buffer B (total analysis time of $120 \mathrm{~min}$ ). Full scans were acquired in the Orbitrap with a scan range of $375-1,400 \mathrm{~m} / \mathrm{z}$, and precursors were sequentially isolated and fragmented with a 30 seconds dynamic exclusion window. MS/MS spectra were acquired in the Orbitrap at a resolution of 30,000 with an AGC target of $1 \mathrm{e} 5$ charges and a maximum injection time of $110 \mathrm{~ms}$.

\section{$\underline{\text { Peptide and protein identification }}$}

Mass spectrometry data were processed with isobarQuant, ${ }^{2,7}$ and the identification of peptide and protein was performed with Mascot 2.4 (Matrix Science) against the human UniProt FASTA (Proteome ID: UP000005640), modified to include known contaminants and the reversed protein sequences (search parameters: trypsin; missed cleavages 3; peptide tolerance $10 \mathrm{ppm}$; MS/MS tolerance $0.02 \mathrm{Da}$; fixed modifications were carbamidomethyl on cysteines and TMT10plex on lysine; variable modifications included acetylation on protein N-terminus, oxidation of methionine, and TMT10plex on peptide Ntermini).

In parallel, the phosphopeptides-enriched raw data files were processed by the MaxQuant software ${ }^{8}$ (version 1.6.2.3) to assess phosphorylation sites localization probabilities. Files were searched against a reviewed Homo sapiens database (UniProt, September 2018), with the following parameters: trypsin digestion (cleavage at the $\mathrm{C}$-term of lysine and arginine, even when followed by a proline residue) with a 
maximum of 3 missed cleavages, TMT10plex labeling, fixed carbamidomethylation of cysteines, variable oxidation of methionines, as well as, variable phosphorylation of serine, threonine and tyrosine residues. Mass tolerance was set to $4.5 \mathrm{ppm}$ at the MS1 level and $20 \mathrm{ppm}$ at the MS2 level. A score cut-off of 40 was used for modified peptides, the false discovery rate was set to 0.01 and the minimum peptide length to 7 residues.

\section{Data preprocessing}

Search results for phosphopeptide-enriched samples from isobarQuant ${ }^{2,7}$ and MaxQuant ${ }^{8}$ were merged based on peptide MS/MS scan ID and kept only for further analysis when they had at least one phosphosite which could be localized with a probability higher than 0.75 (extracted from MaxQuant output) — to only include phosphosites with high localization confidence, generally termed class I phosphosites ${ }^{9}$-, signal to interference ratio (S2I) equal or higher than 0.5 and precursor to threshold ratio (P2T) equal or higher than 4 (both extracted from isobarQuant output) - to minimize ratio compression originating from co-isolated peptides ${ }^{1}$. Peptides with identical sequence and phosphorylation localization were merged by summing their signal intensities. Search results for the non-modified fraction were used only based on isobarQuant output parameters requesting that peptides were unique for the protein, a Mascot score of higher than 20 and an FDR lower than 0.01. Measured signals for each unique peptide in each replicate and condition were transformed into fold-changes by dividing signal intensities by each corresponding measurement at the lowest temperature $\left(37^{\circ} \mathrm{C}\right)$.

\section{$\underline{\text { Data normalization }}$}

To normalize the fold-changes of each phosphopeptide enriched sample to each respective non-modified sample, we retrieved normalization-factors to align median fold changes at each temperature of jointly identified non-modified peptides. This was implemented by finding overlapping non-modified peptides between matching replicates of phosphopeptide enriched and non-modified samples fulfilling the following filter criteria: $7^{\text {th }}$ temperature should be between 0.3 and 0.7 , fold change at $9^{\text {th }}$ temperature should be between 0 and 0.4 , and fold change at $10^{\text {th }}$ temperature should be between 0 and 0.2 . Then, normalizationfactors were determined for fold changes at each temperature by computing the ratio between the median fold change of these peptides in the non-modified and phosphopeptide enriched samples. Finally, retrieved normalization-factors were applied to normalize the fold changes at each measured temperature of all peptides within the phosphopeptide enriched sample.

Next, we applied a previously described curve-based normalization procedure between replicates of the non-bound fraction samples. ${ }^{10}$ Briefly, this involved: i) building the set of overlapping peptides between all 
datasets; ii) filtering these peptides to fulfill the following criteria: fold change measured at $3^{\text {rd }}$ temperature should be higher than 1 , fold change at $7^{\text {th }}$ temperature should be between 0.3 and 0.7 , fold change at $9^{\text {th }}$ temperature should be between 0 and 0.4 , and fold change at $10^{\text {th }}$ temperature should be between 0 and 0.2 ; iii) finding the largest subset of peptides fulfilling these criteria in either of the replicates; iv) fitting a melting curve to the median fold change of the set of selected peptides for each replicate; v) the replicate yielding the highest $\mathrm{R}^{2}$ value was selected and normalization factors for each of the replicates were obtained by computing the fractions of fold changes predicted by that melting curve at each given temperature and the median fold changes measured for each respective replicate; vi) retrieved normalization factors were then applied to both the non-modified fraction and the respective phosphopeptide-enriched replicates.

\section{Melting curve fitting}

Melting curves were fitted to each replicate of each phosphopeptide separately using the $d r c \mathrm{R}$ package ${ }^{11}$ with the sigmoidal LL.4 model:

$$
\mu(T)=\text { plateau }+\frac{1-\text { plateau }}{1+\exp (b(T-a))}
$$

Where $T$ is the temperature, plateau is the lower bound, $b$ is the slope and $a$ the inflection point. The melting point $\left(\mathrm{T}_{\mathrm{m}}\right)$ was estimated from the temperature at which $\mu(T)=0.5$, from curves for which $\mathrm{R}^{2}>0.8$ and plateau $<0.2$.

For the non-modified fraction all peptides mapping to the same protein were jointly fitted per replicate using (1).

\section{Detecting differentially melting phosphopeptides}

Assessment of differential melting of phosphopeptides compared to all peptides of a given protein in the non-bound fraction was based on inferred melting point $\left(\mathrm{T}_{\mathrm{m}}\right)$ comparisons. As previously described,,$^{2} \Delta \mathrm{T}_{\mathrm{m}}$ were compared using z-tests and retrieved p-values were adjusted for multiple testing using the method of Benjamini and Hochberg. ${ }^{12}$ Phosphopeptides were accepted as significant hits, when at least two replicates were found with an adjusted $\mathrm{p}$-value $<0.1$ and all $\Delta \mathrm{T}_{\mathrm{m}}$ (including non-significant) had consistent signs. 
bioRxiv preprint doi: https://doi.org/10.1101/2020.01.14.903849; this version posted January 14,2020. The copyright holder for this preprint (which was not certified by peer review) is the author/funder, who has granted bioRxiv a license to display the preprint in perpetuity. It is made available under aCC-BY-NC-ND 4.0 International license.

Data and code availability

The mass spectrometry proteomics data have been deposited to the ProteomeXchange Consortium via the PRIDE partner repository with the dataset identifier PXD015993. All code to reproduce the analysis is available at https://github.com/nkurzaw/phosphoTPP. 


\section{Supplementary discussion}

\section{$\underline{\mathrm{T}_{\mathrm{m}}}$ estimate reproducibility}

Huang et al. ${ }^{13}$ assessed data reproducibility by comparing the average $T_{m}$ from biological replicates 1-3 to the average $T_{m}$ from biological replicates 4-6 of the non-modified protein samples (original Supplementary figure 2 in Huang et al. ${ }^{13}$ ), which yielded a coefficient of determination $\left(\mathrm{R}^{2}\right)$ of 0.7 . However, when determining the reproducibility of individual replicates, using the original data from Supplementary Table 1 and 2 in Huang et al. ${ }^{13}$, we found poor correlation between all replicates — both biological (average $\mathrm{R}^{2}$ for phosphorylated peptides $=0.21$ and average $\mathrm{R}^{2}$ for non-modified proteins $=0.42$ ) and technical (average $\mathrm{R}^{2}$ for phosphorylated peptides $=0.36$ and average $\mathrm{R}^{2}$ for non-modified proteins $=0.62$ ).

We have previously shown, ${ }^{10}$ and reconfirmed here, that $\mathrm{T}_{\mathrm{m}}$ estimates for non-modified proteins are reproducible (average $\mathrm{R}^{2}$ of 0.86; Supplementary Fig. 5), even when considering different studies and different laboratories $\left(\mathrm{R}^{2}=0.82\right.$ (same cell line in our lab ${ }^{14}$ ); $\mathrm{R}^{2}=0.69$ (different cell line in different lab ${ }^{15}$ ); Supplementary figure 7). Here, we also observed that the same is true for phosphorylated peptides (Supplementary Figure 6).

Therefore, we showed that protein and peptide $\mathrm{T}_{\mathrm{m}}$ estimation is reproducible, and that the lack of reproducibility in Huang et al. ${ }^{13}$ might influence their results. The reasons for this poor reproducibility are explored in this work, and we provide a complete protocol and data analysis pipeline to achieve high quality data.

\section{$\underline{\text { Peptide labeling and phosphopeptide enrichment }}$}

In the work of Huang et al. ${ }^{4}$, the authors, after digesting the soluble protein fraction, saved an aliquot of peptides from each temperature ( $5 \%$ of sample) to estimate the $T_{m}$ of the non-modified proteins. With the remaining $95 \%$ of peptide samples, the authors performed separate phosphopeptide enrichments using $\mathrm{TiO}_{2}$ tips for each temperature. Two main problems might arise from this approach: i) the separate isobaric labeling of the non-modified and corresponding phosphorylated peptides from the same replicate might introduce unnecessary variability - however, tandem mass tags (TMT) labeling, when the TMT reagent is in stoichiometric excess, generally yields reproducible results, ${ }^{16}$ and therefore this might not be the major contributor to the poor reproducibility of the Huang et al. dataset; ii) the separate phosphopeptide enrichments using $\mathrm{TiO}_{2}$ tips for each temperature could introduce larger errors. In quantitative phosphoproteomics, enrichment protocols generally suggest that equal amounts of peptides are used for each conditions. In thermal proteome profiling (TPP) experiments, there are large differences in peptide amounts, in general in the order of 10-fold between the lowest temperature (high peptide amount) and the highest temperature (low peptide amount), which will translate in large differences in peptide input/TiO ${ }_{2}$ 
ratio between the different temperatures - since the amount of $\mathrm{TiO}_{2}$ packed in the tips is not adjusted for each sample. It has been shown that the ratio between peptide and stationary phase is critical to achieve good enrichment selectivity, ${ }^{17}$ and the poor enrichment selectivity observed in the Huang et al. work (phosphopeptides representing roughly $60 \%$ of the total peptides identified, while nowadays more than $90 \%$ specificity is routinely achieved $-98 \%$ in our study) is thus an indication that the way the authors performed phosphopeptide enrichment is suboptimal. Further, the enrichment selectivity of Huang et al. was variable from sample to sample, as analyzed in an accompanying work by Smith et al. ${ }^{18}$. Importantly, the authors did not validate the linearity of enrichment capacity over a broad range of peptide amount input, and therefore this step might negatively influence their results by introducing quantification biases which will impact the estimation of phosphopeptide melting points - particularly, for an approach with low amount of $\mathrm{TiO}_{2}$ stationary phase $\left(\mathrm{TiO}_{2}\right.$ spin tips used by the authors, catalog no. 88303, Thermo Fisher Scientific). This lack of linearity of enrichment capacity over a broad range of peptide input amount was previously observed in the case of enrichment performed by $\mathrm{Fe}^{3+}$-IMAC in tip format ${ }^{19,20}$, but the same remains to be checked for the $\mathrm{TiO}_{2}$ tips used in the Huang et al. study.

All in all, we suggest that a single round of TMT labeling should be performed, and that phosphorylated peptides should be enriched once pooled together. The major disadvantage of this approach is the large amount of TMT reagents needed, since phosphorylated protein forms are generally present at low amounts. However, if a linear enrichment procedure is used, it might be possible to perform TMT labeling postenrichment.

\section{Mass spectrometry analysis}

Huang et al. ${ }^{13}$ quantified their peptides by analyzing them directly after labeling on an Orbitrap Q-Exactive HF mass spectrometer coupled to liquid chromatography (LC). By exploring the raw data deposited in the MassIVE repository (identifier: MSV000083786), we observed that their effective gradient time is generally lower than $2 \mathrm{~h}$ (total analysis time of $2.5 \mathrm{~h}$ to $4.3 \mathrm{~h}$ depending on the replicates) and that an isolation window of $1.2 \mathrm{~m} / \mathrm{z}$ was used. The high complexity of their samples suggests that the gradients are too short to properly separate peptides and avoid co-isolation during MS2 scans — which is critical for TMT based quantification as peptide co-fragmentation leads to TMT ratio compression. ${ }^{1}$ Indeed, we reprocessed the original data using the MaxQuant software (as described in the methods section), and observed low Parent Ion Fraction (PIF, which represents the ratio of the intensity of selected precursor ions over the summed intensities of all ions present in the isolation window) for the majority of both phosphorylated (median [interquartile range]: 0.78 [0.63-0.90]) and non-modified peptides (0.77 [0.62-0.90]). Our samples, which were pre-fractionated using high $\mathrm{pH}$ LC prior to the LC gradient in front of the mass spectrometer, yielding an effective gradient time higher than $20 \mathrm{~h}$ (total gradient time of $24 \mathrm{~h}$ ), resulted in a high PIF 
(phosphorylated 0.90 [0.78-0.96] and non-modified 0.90 [0.78-0.97] peptides) (Supplementary figure 9). It should be noted that we also used a narrower isolation window of $0.7 \mathrm{~m} / \mathrm{z}$ to further reduce co-isolation. The high co-isolation observed by Huang et al. ${ }^{13}$ led to a poor reproducibility of $\mathrm{T}_{\mathrm{m}}$ estimates (Supplementary Figs. 2-3), a compressed distribution of $\mathrm{T}_{\mathrm{m}}$ for non-modified proteins (Supplementary Fig. 7) and a poor correlation between $T_{m}$ of non-modified and phosphorylated proteoforms, which biased all the downstream analyses by the authors - since this caused $\mathrm{T}_{\mathrm{m}}$ comparisons between phosphorylated and non-phosphorylated proteoforms to deviate from the unity line and appear as significant hits (Fig. 1A). This is further highlighted by the narrower distribution of differences in $\mathrm{T}_{\mathrm{m}}$ between proteins and corresponding phosphorylated proteoforms in our experiments (standard deviation of $1.53{ }^{\circ} \mathrm{C}$ ) compared to Huang et al. ${ }^{13}$ (standard deviation $2.37^{\circ} \mathrm{C}$; Supplementary Fig. 9).

Overall, we recommend that complex TMT labelled samples be pre-fractionated to reduce sample complexity and avoid ratio compression. ${ }^{1}$ 


\section{Supplementary data description}

Supplementary data 1. Phosphopeptide fold-changes at each temperature in each replicate. (gene_name: Gene name; protein_id: Uniprot ID; sequence: peptide sequence; mod_sequence: modified peptide sequence; phospho_site_STY: number of modified aminoacids in the peptide sequence; rel_fc_TMT_REP_TEMP: relative fold-changes to $37^{\circ} \mathrm{C}$ (TMT: TMT label; REP: replicate; TEMP: temperature).

Supplementary data 2. Non-modified peptide fold-changes at each temperature in each replicate. (gene_name: Gene name; protein_id: Uniprot ID; sequence: peptide sequence; modifications: peptide modifications; rel_fc_TMT_REP_TEMP: relative fold-changes to $37^{\circ} \mathrm{C}$ (TMT: TMT label; REP: replicate; TEMP: temperature).

\section{Supplementary data 3. Comparison of melting behavior of phosphopeptide and non-modified} peptides. (gene_name: Gene name; Gene_pSite: Phosphosite position within protein; mod_sequence: modified peptide sequence; mean_phospho: average melting temperature of phosphopeptide; mean_nbf: average melting temperature of non-modified protein; mean_delta_meltPoint: average difference of melting temperature of phosphopeptide and non-modified protein; significant: significantly different melting temperature of phosphopeptide compared to non-modified protein; functional_score: predicted functional importance of phosphosite position, by aggregating multiple parameters for each phosphosite using machine learning and ranges from 0 to 1 , with a higher value representing a higher probability that the phosphosite has functional relevance; Tm_phospho_REP: melting temperature of phosphopeptide (REP: replicate); Tm_nbf_REP: melting temperature of non-modified protein (REP: replicate); delta_meltPoint_REP: difference of melting temperature of phosphopeptide and non-modified protein (REP: replicate); p_adj_REP: p-value adjusted for multiple testing correction (REP: replicate); phospho_median_fc_TEMP: median relative fold-changes to $37^{\circ} \mathrm{C}$ of phosphopeptide (TEMP: temperature); nbf_median_fc_TEMP median relative fold-changes to $37^{\circ} \mathrm{C}$ of non-modified protein (TEMP: temperature). 
bioRxiv preprint doi: https://doi.org/10.1101/2020 01.14 903849; this version posted January 14,2020 . The copyright holder for this preprint (which was not certified by peer review) is the author/funder, who has granted bioRxiv a license to display the preprint in perpetuity. It is made available under aCC-BY-NC-ND 4.0 International license.

\section{Supplementary figures}

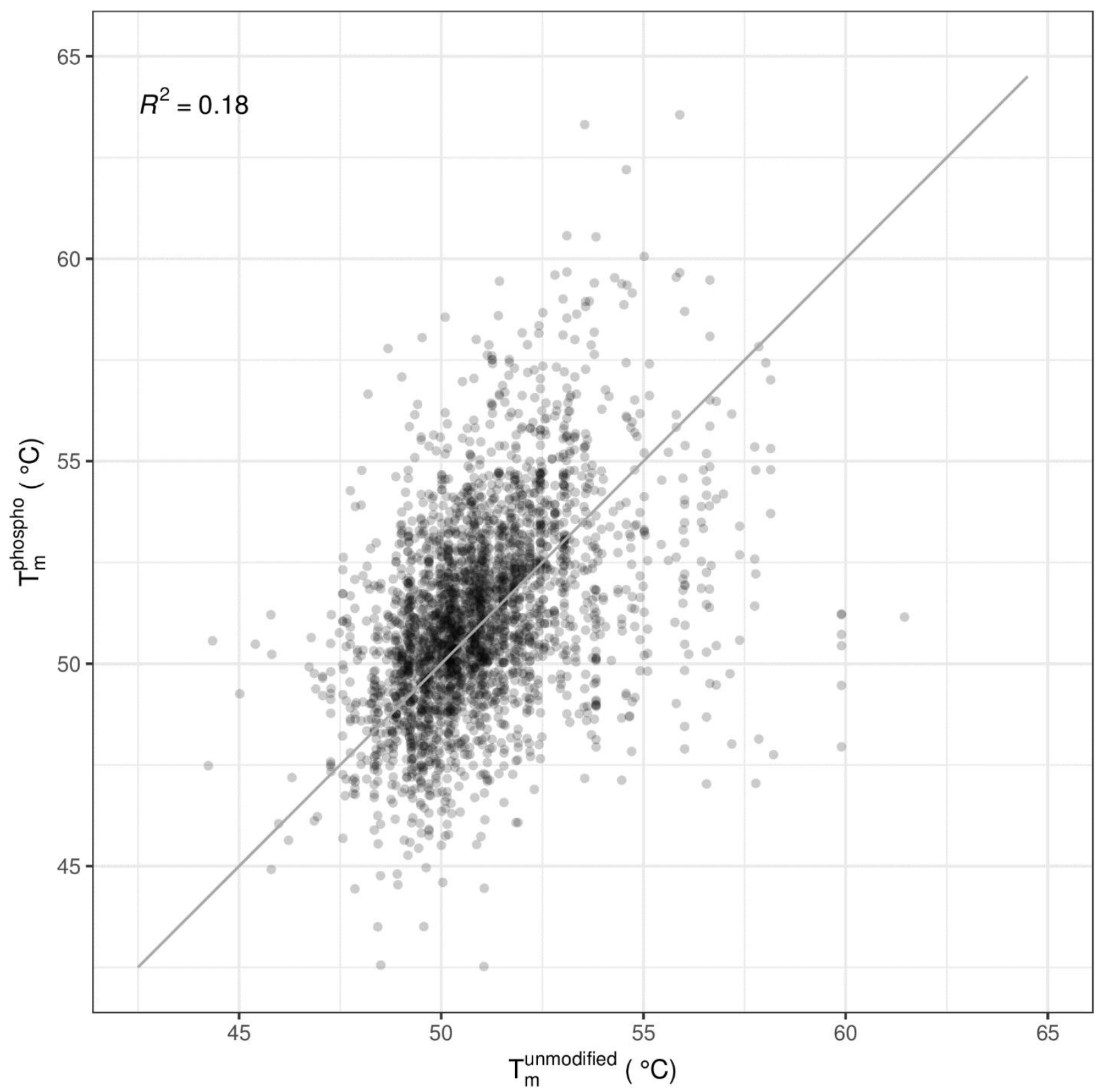

Supplementary figure 1. Comparison of non-modified and phosphorylated protein $\mathbf{T}_{\mathrm{m}}$ estimates from

Huang et al. Data collected from supplementary tables 1 and 2 of Huang et al. for high confidence $\mathrm{T}_{\mathrm{m}}$ estimates and average of all replicates. 
bioRxiv preprint doi: https://doi.org/10.1101/2020.01.14.903849; this version posted January 14,2020 . The copyright holder for this preprint (which was not certified by peer review) is the author/funder, who has granted bioRxiv a license to display the preprint in perpetuity. It is made available under aCC-BY-NC-ND 4.0 International license.

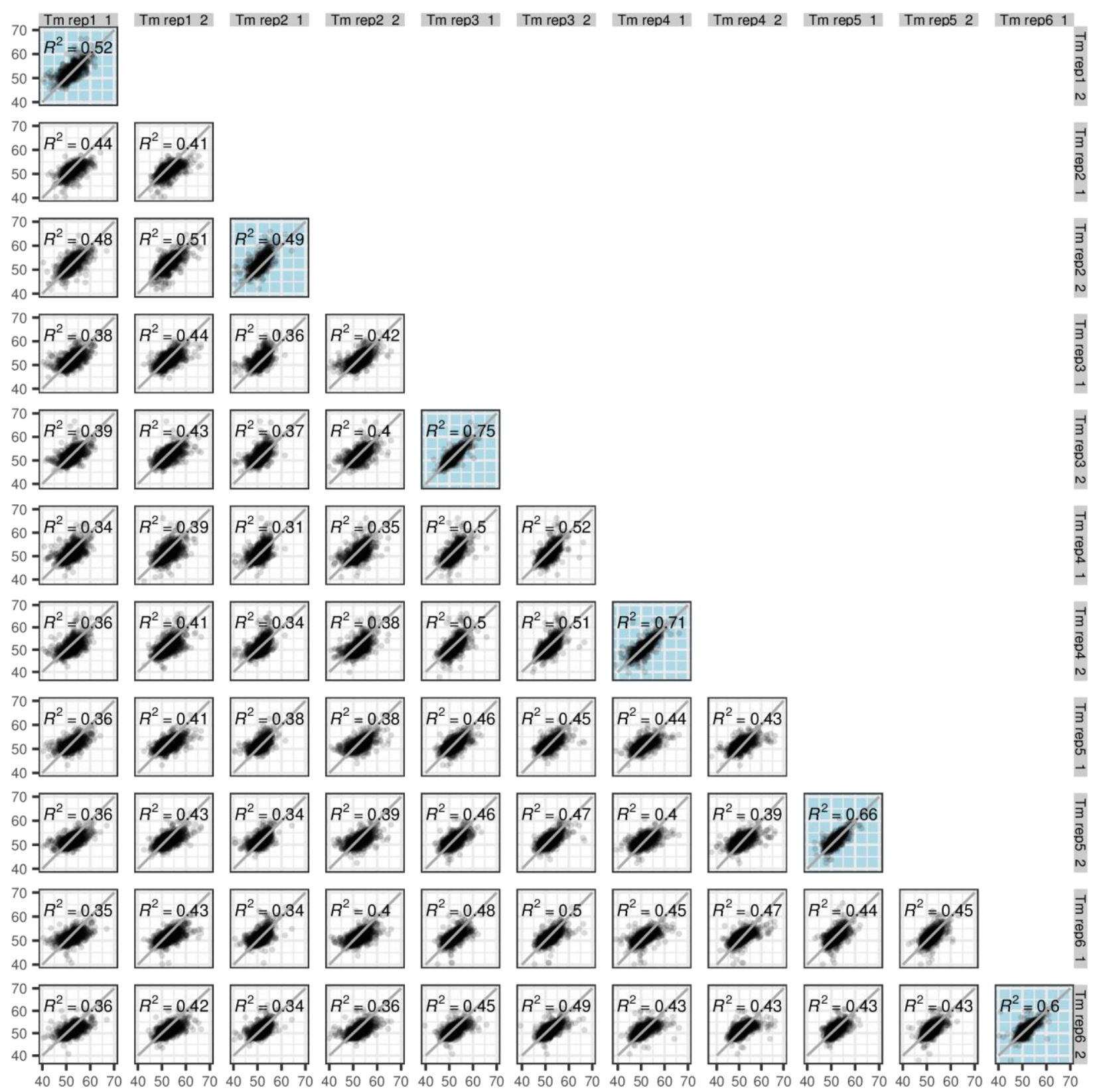

Supplementary figure 2. Reproducibility of non-modified sample $\mathbf{T}_{\mathrm{m}}$ estimates by Huang et al.

Displayed $\mathrm{T}_{\mathrm{m}}$ are represented in degree Celsius, the gray line is the identity line, plots with colored background represent technical replicates according to the labelling by Huang et al. Of note, the data could not be filtered according to the high quality criteria used by Huang et al. because this information was not annotated in the supplementary table supplied. 
bioRxiv preprint doi: https://doi.org/10.1101/2020 01.14 903849; this version posted January 142020 . The copyright holder for this preprint (which was not certified by peer review) is the author/funder, who has granted bioRxiv a license to display the preprint in perpetuity. It is made available under aCC-BY-NC-ND 4.0 International license.

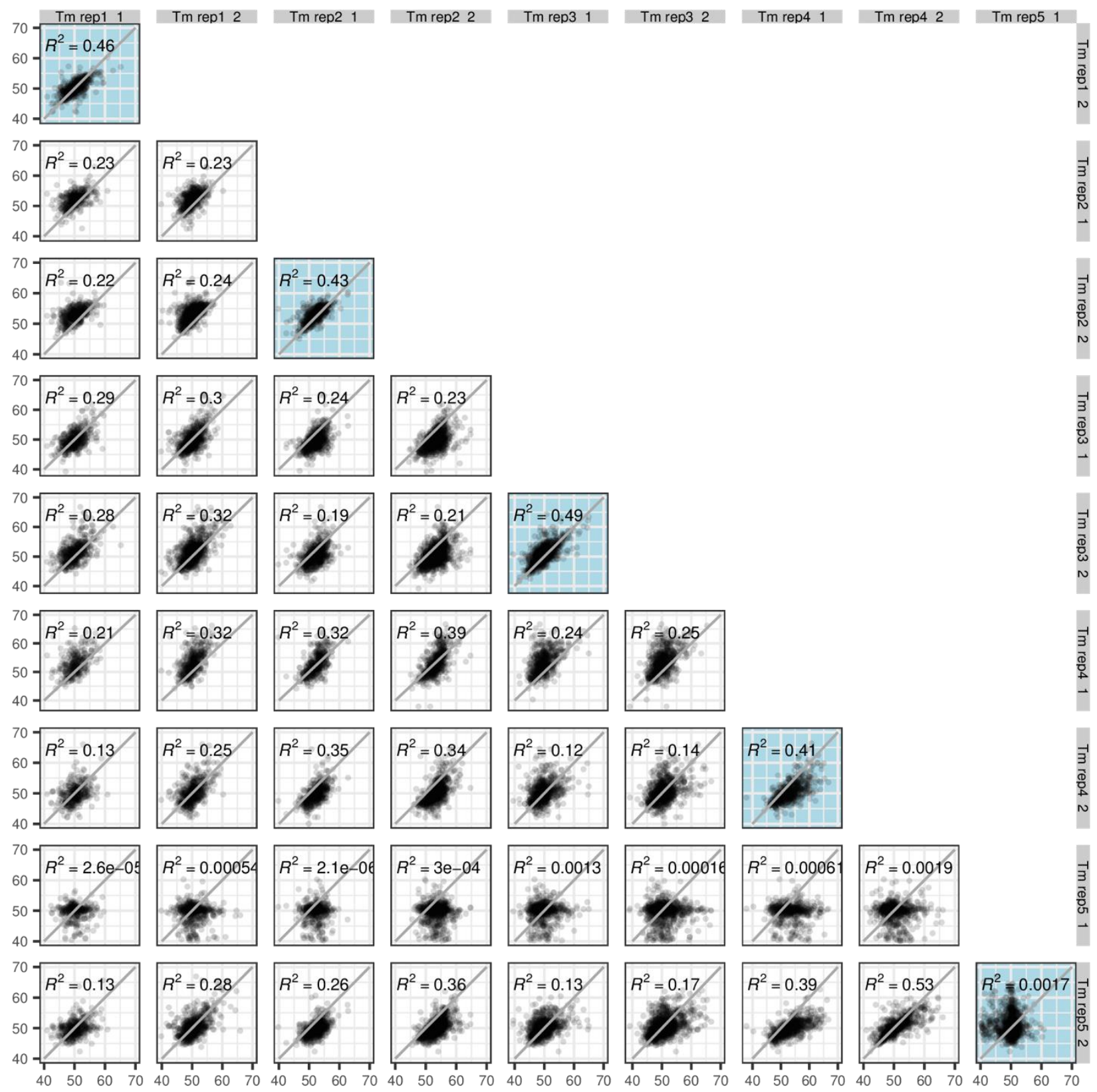

Supplementary figure 3. Reproducibility of high confidence phosphorylated protein $\mathbf{T}_{\mathrm{m}}$ estimates by

Huang et al. Displayed Tm are represented in degree Celsius, the gray line is the identity line, plots with colored background represent technical replicates according to the labelling by Huang et al. 


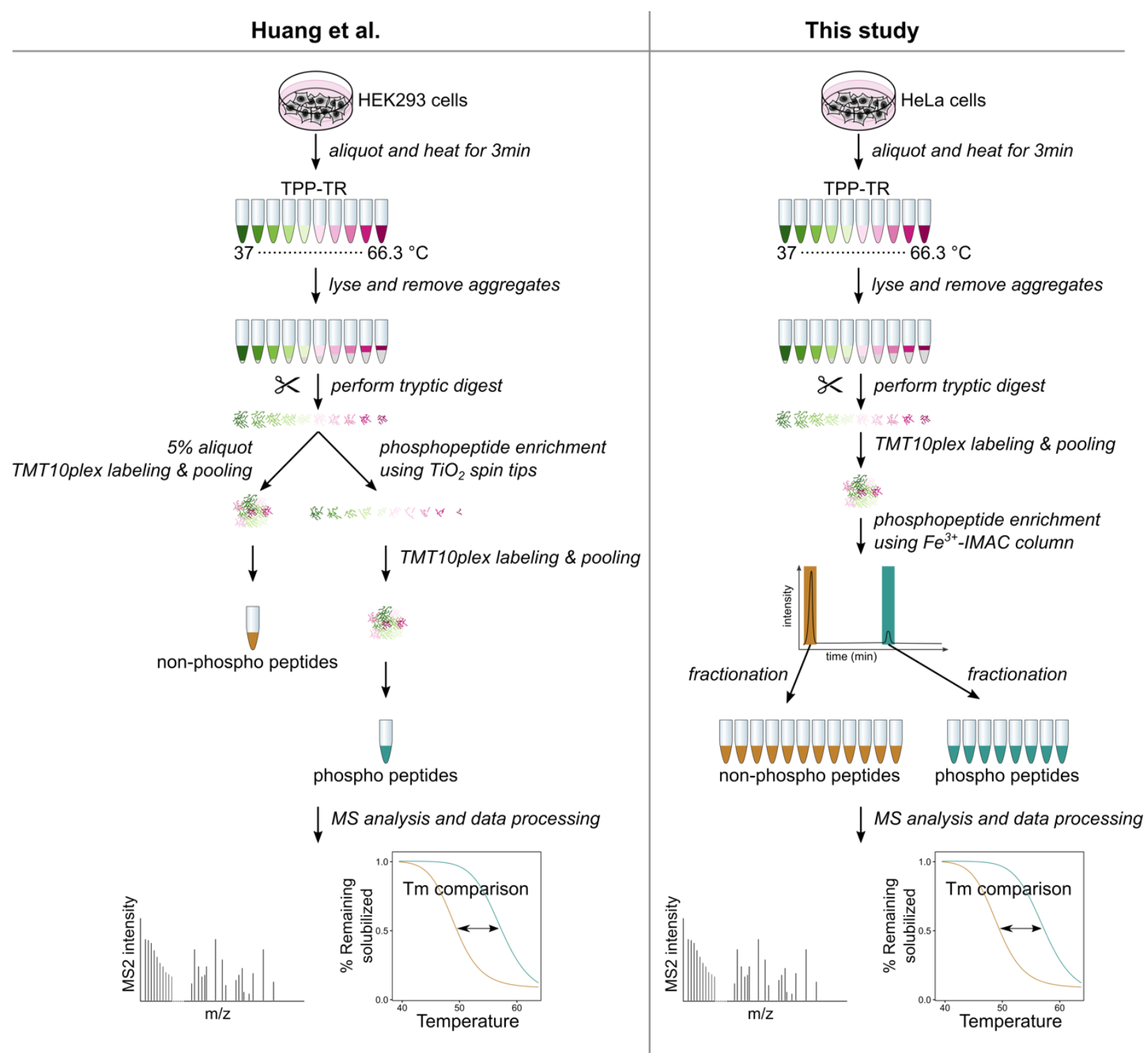

Supplementary figure 4. Comparison of workflow from Huang et al. and that of this study. In this study, HeLa cells were heated to ten different temperatures. After lysis, the remaining soluble proteins were collected, digested and TMT labeled. Phosphopeptides were enriched using an iron ion-immobilized metal affinity chromatography ( $\mathrm{Fe}^{3+}$-IMAC) column and fractionated onto six fractions. The flow-through of the enrichment (non-modified) was fractionated onto twelve fractions. All samples were analyzed on a Fusion Lumos Orbitrap coupled to liquid chromatography. 
bioRxiv preprint doi: https://doi. org/10.1101/2020 01.14 903849. this version posted January 142020 . The copyright holder for this preprint (which was not certified by peer review) is the author/funder, who has granted bioRxiv a license to display the preprint in perpetuity. It is made available under aCC-BY-NC-ND 4.0 International license.
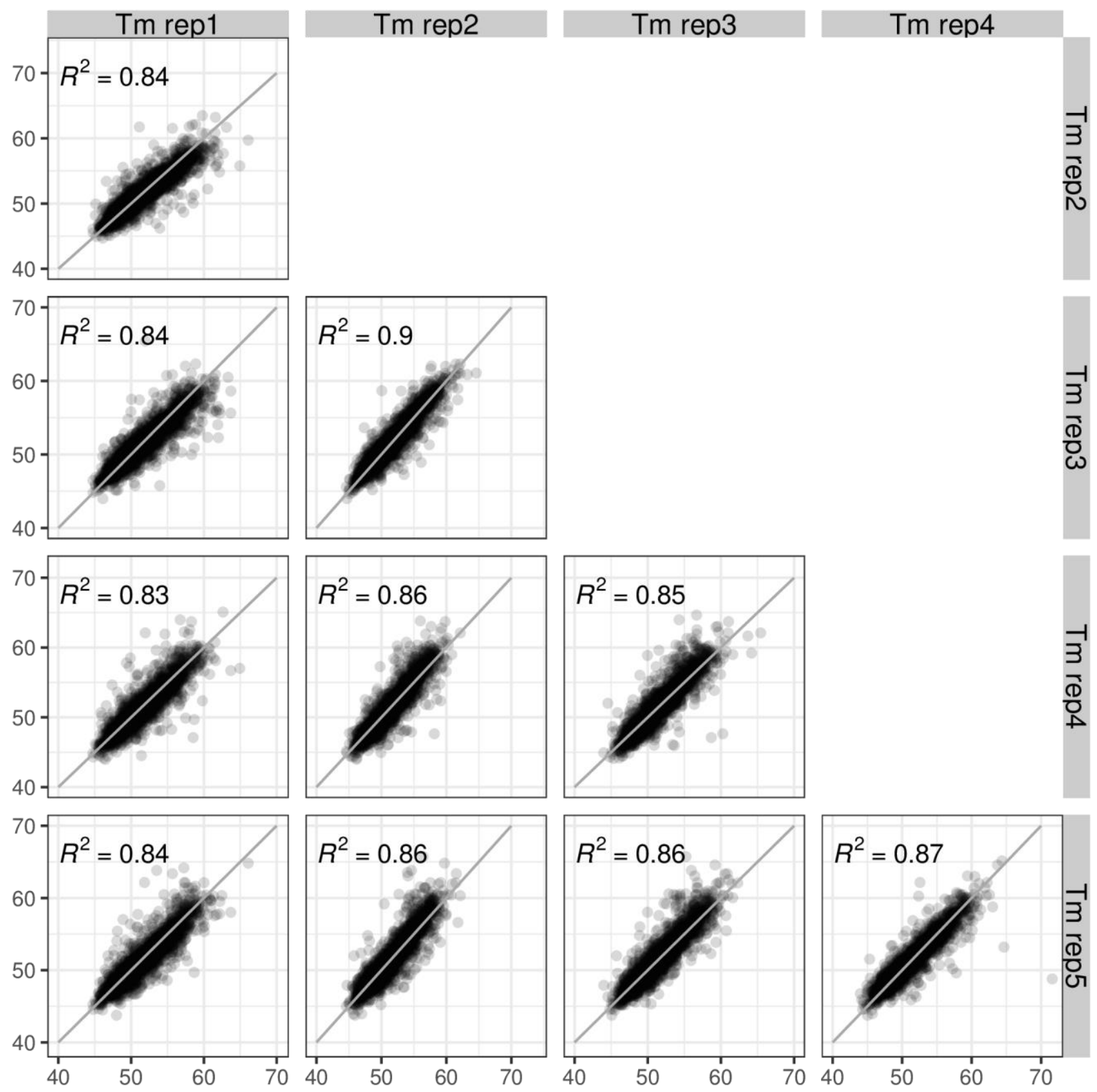

Supplementary figure 5. Reproducibility of non-modified sample $\mathbf{T}_{\mathbf{m}}$ estimates from this study. Displayed $\mathrm{T}_{\mathrm{m}}$ are represented in degree Celsius, the gray line is the identity line. 
bioRxiv preprint doi: https://doi. org/10.1101/2020 $01.14 .903849 \cdot$ this version posted January 142020 . The copyright holder for this preprint (which was not certified by peer review) is the author/funder, who has granted bioRxiv a license to display the preprint in perpetuity. It is made available under aCC-BY-NC-ND 4.0 International license.
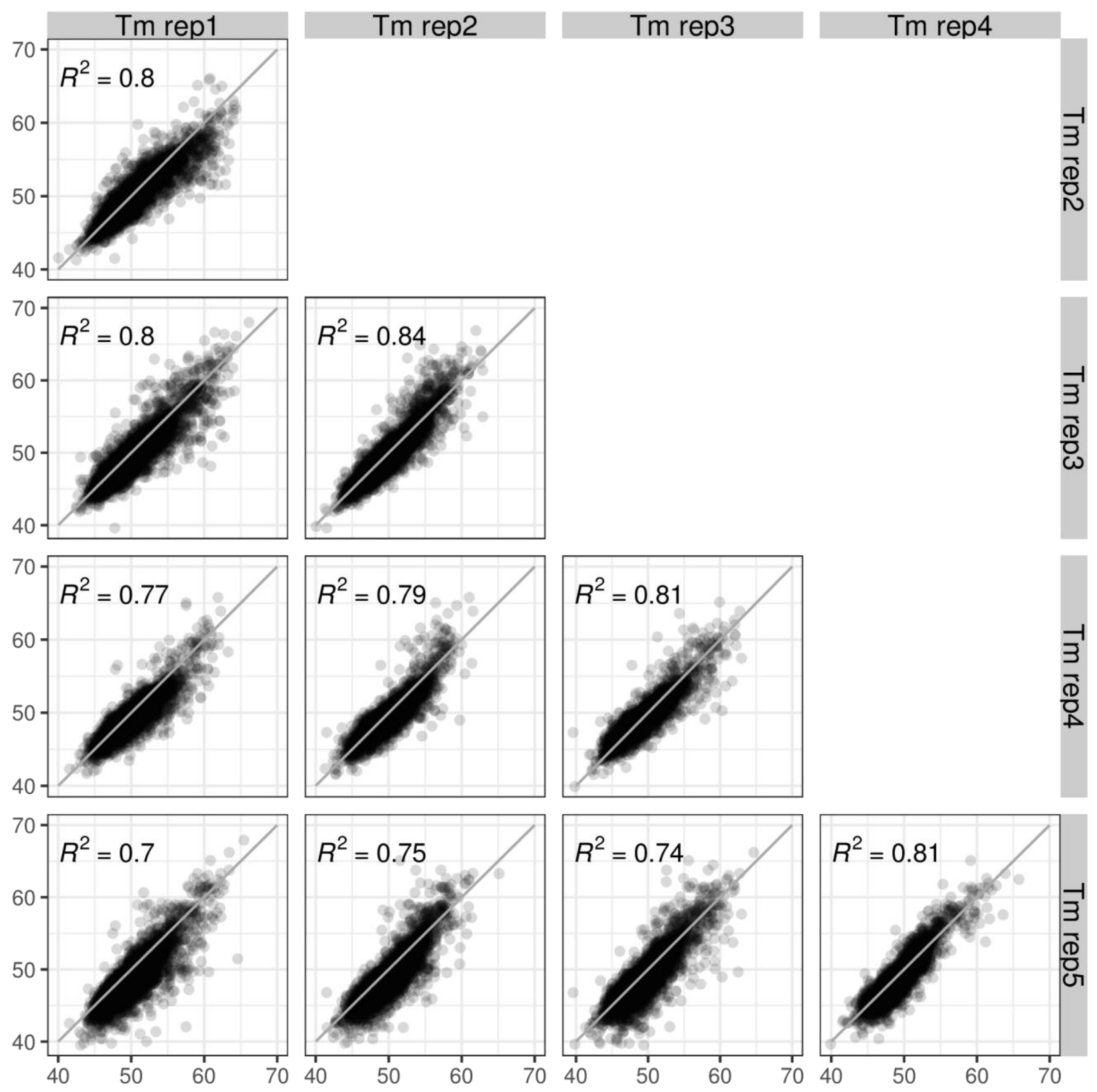

Supplementary figure 6. Reproducibility of phosphorylated protein $T_{m}$ estimates from this study. Displayed $\mathrm{T}_{\mathrm{m}}$ are represented in degree Celsius, the gray line is the identity line. 

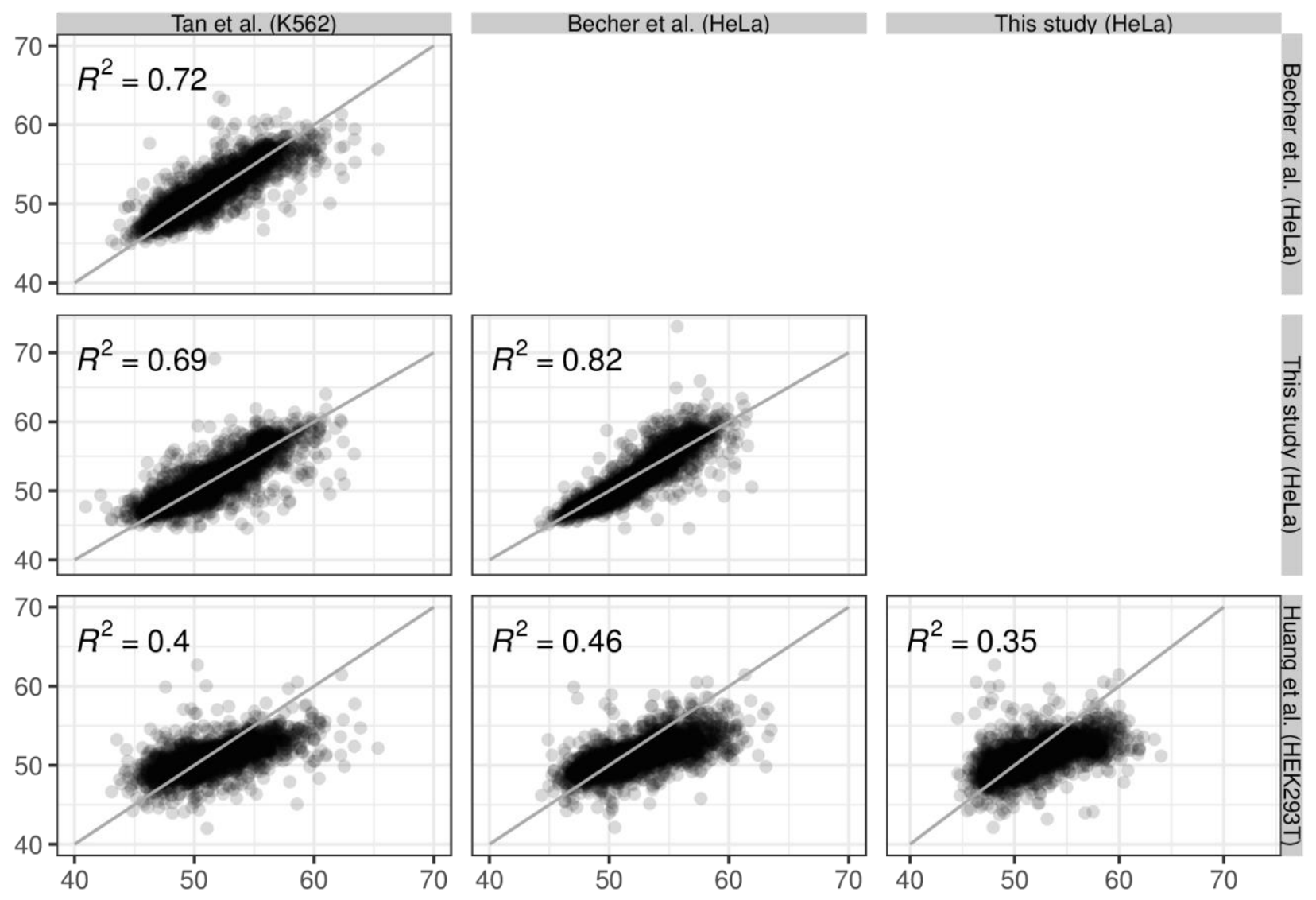

Supplementary figure 7. Comparison of $T_{m}$ estimates from Huang et al and this study with previously published datasets. Displayed $\mathrm{T}_{\mathrm{m}}$ are represented in degree Celsius, the gray line is the identity line. The data from Tan et al. ${ }^{21}$ was retrieved from supplementary table S7 of their publication (K562 cells; using similar acquisition parameters as our work) and fitted using the procedure described in this study. Data from Becher et al. ${ }^{14}$ was retrieved directly from supplementary table S4 (HeLa cells in G1/S phase). 

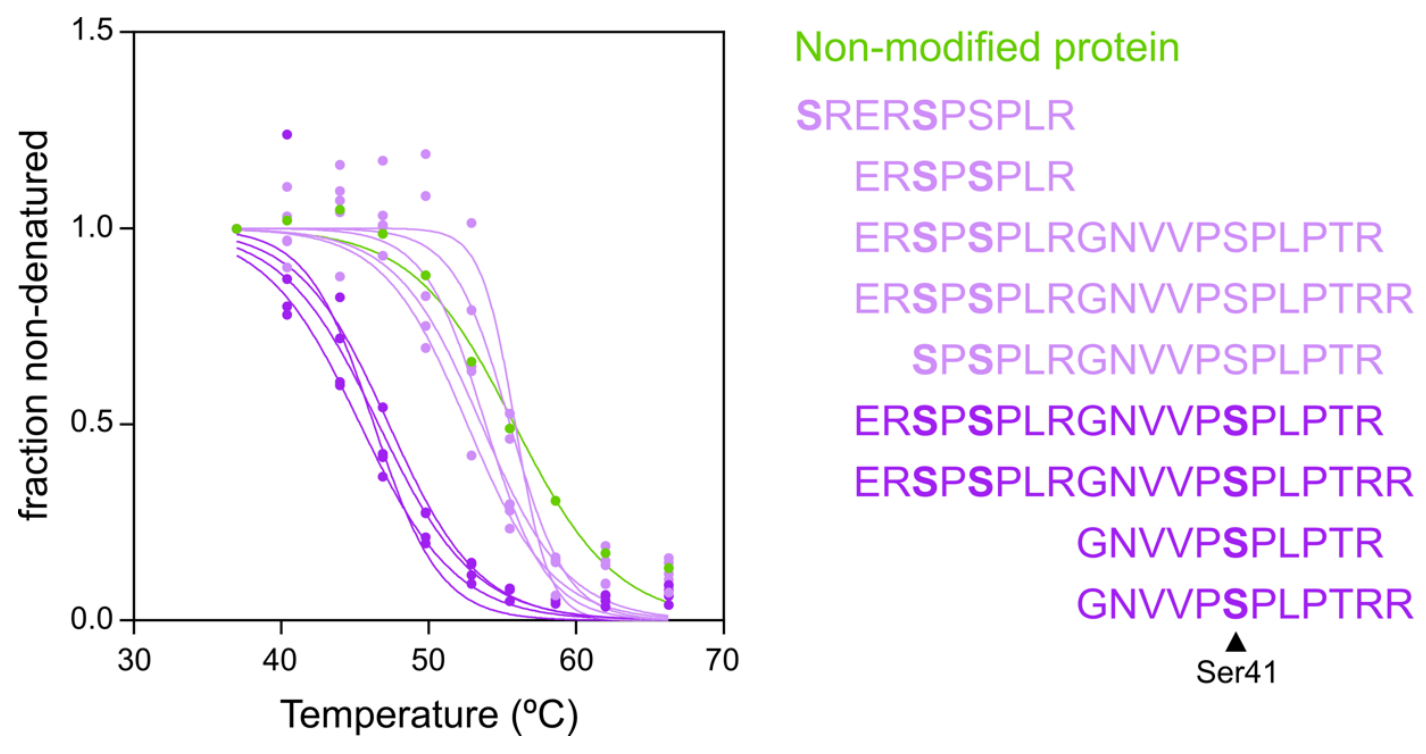

Supplementary figure 8. Melting curves of phosphopeptides and non-modified CARHSP1. Bold in the figure legend indicates phosphorylated site. 
bioRxiv preprint doi: https://doi.org/10.1101/2020 $01.14 .903849 \cdot$ this version posted January 14,2020 . The copyright holder for this preprint (which was not certified by peer review) is the author/funder, who has granted bioRxiv a license to display the preprint in perpetuity. It is made available under aCC-BY-NC-ND 4.0 International license.

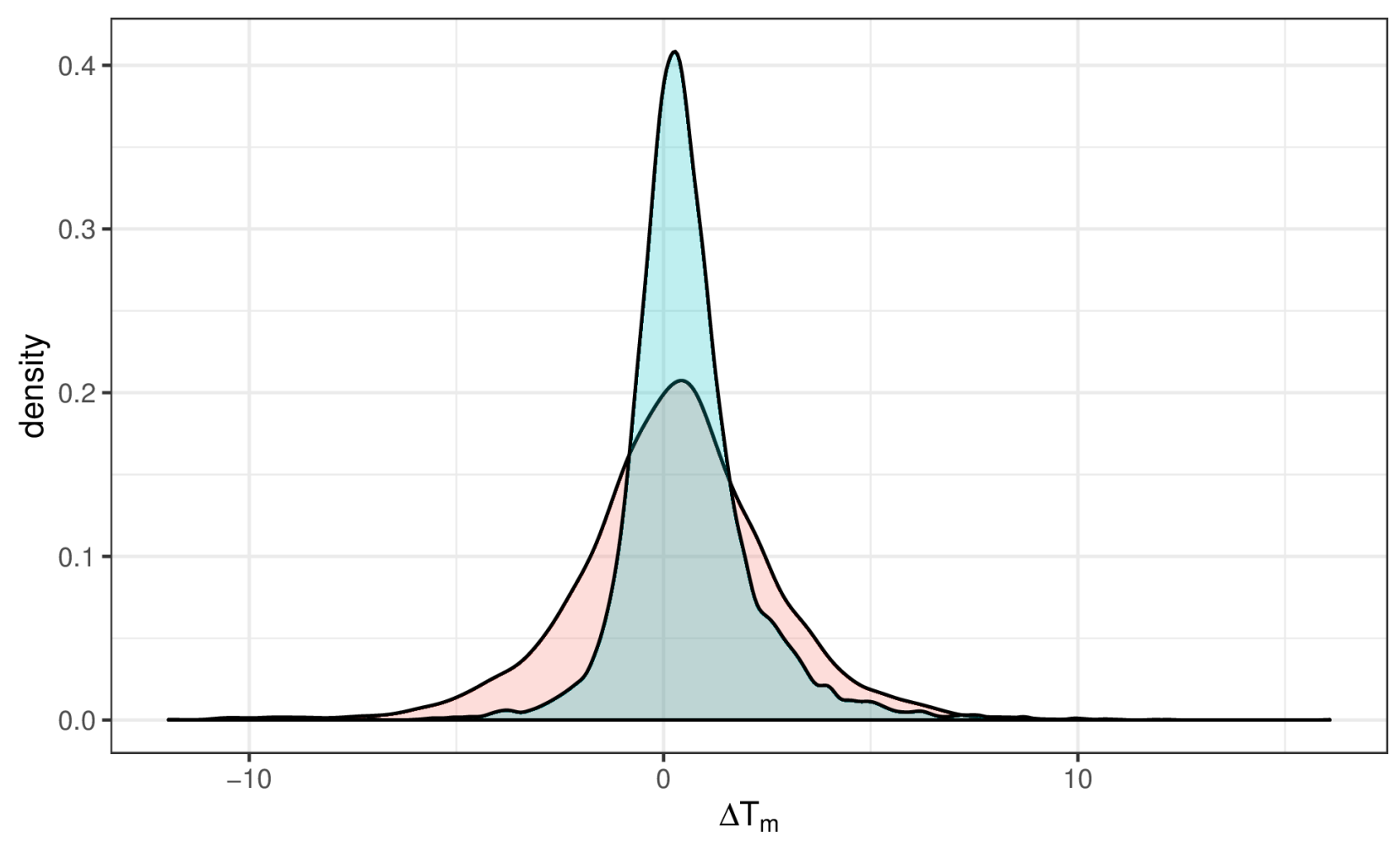

dataset $\square$ Huang et al. $\square$ This study

Supplementary figure 9. Comparison of $\Delta \mathrm{Tm}$ distribution between the two studies. 
bioRxiv preprint doi: https://doi.org/10.1101/2020.01.14.903849; this version posted January 14,2020 . The copyright holder for this preprint (which was not certified by peer review) is the author/funder, who has granted bioRxiv a license to display the preprint in perpetuity. It is made available under aCC-BY-NC-ND 4.0 International license.

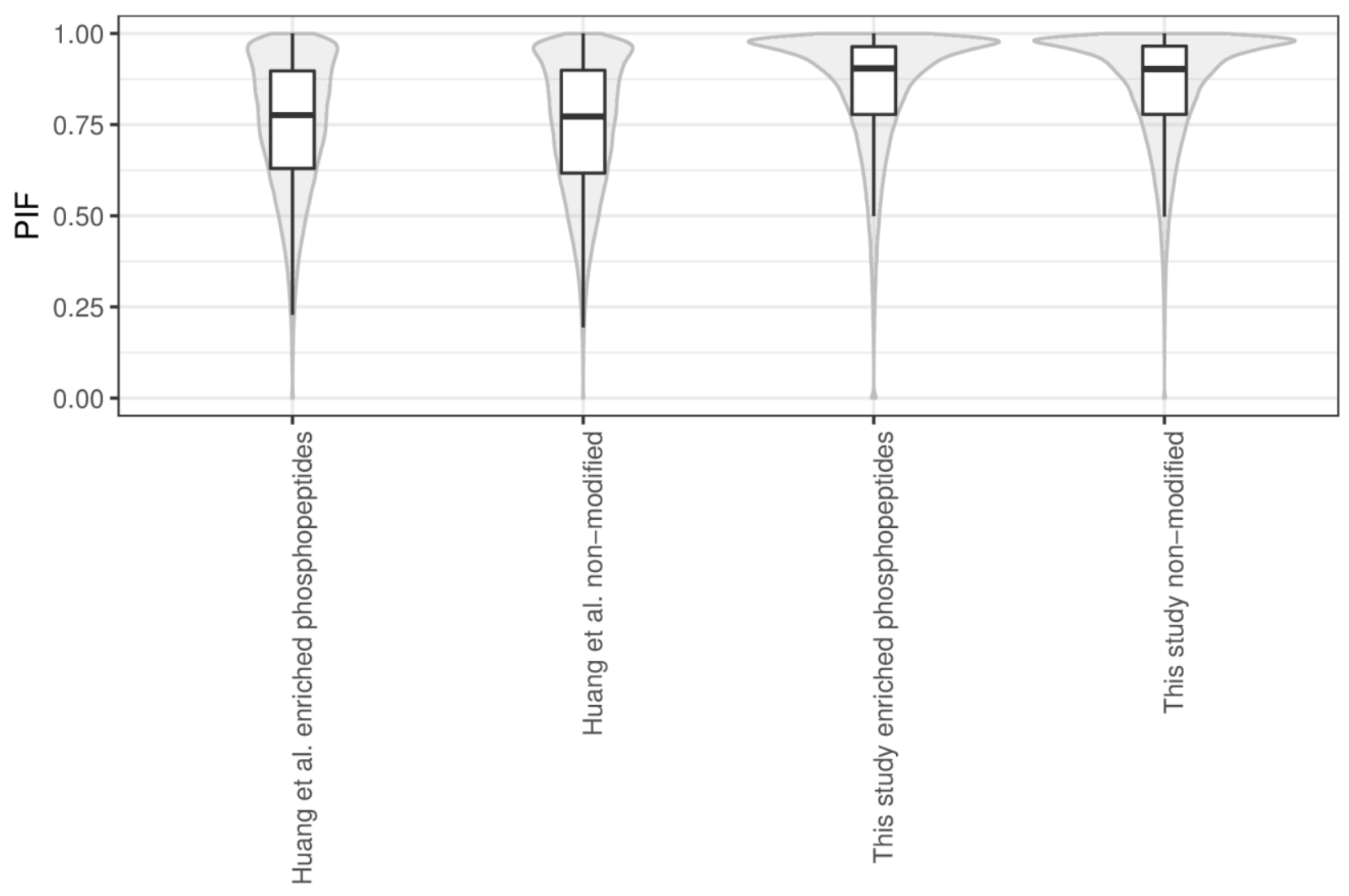

Supplementary figure 10. Parent ion fraction (PIF) distribution for the datasets from Huang et al. and this study. 


\section{Supplementary table}

Supplementary table 1. Protocol differences between the approach used in this study and that in

\section{Huang et al. ${ }^{13}$}

\section{Differences in the protocol presented in this Reason for change study compared to Huang et al. ${ }^{13}$}
Peptide labeling with tandem mass tags (TMT) To avoid two rounds of TMT labeling and to prior to phosphopeptide enrichment ensure that phosphopeptide enrichment does not bias the analysis due to different peptide input
from samples from different temperatures

Peptide pre-fractionation prior to mass spectrometry analysis

Data normalization prior to $\mathrm{T}_{\mathrm{m}}$ estimation (between phosphopeptide and non-modified protein samples and between different replicates)

Statistical analysis with multiple testing correction
To avoid peptide co-isolation during MS2 scans, which leads to ratio compression ${ }^{1}$, which leads to a narrower distribution of $\mathrm{T}_{\mathrm{m}}$

To ensure that different MS experiments are comparable to each other

To reduce the false positive rate 


\section{Supplementary references}

1 Savitski, M. M. et al. Measuring and managing ratio compression for accurate iTRAQ/TMT quantification. J Proteome Res 12, 3586-3598, doi:10.1021/pr400098r (2013).

2 Franken, H. et al. Thermal proteome profiling for unbiased identification of direct and indirect drug targets using multiplexed quantitative mass spectrometry. Nat Protoc 10, 1567-1593, doi:10.1038/nprot.2015.101 (2015).

3 Reinhard, F. B. et al. Thermal proteome profiling monitors ligand interactions with cellular membrane proteins. Nat Methods 12, 1129-1131, doi:10.1038/nmeth.3652 (2015).

4 Potel, C. M., Lin, M. H., Heck, A. J. R. \& Lemeer, S. Defeating Major Contaminants in Fe(3+)Immobilized Metal Ion Affinity Chromatography (IMAC) Phosphopeptide Enrichment. Mol Cell Proteomics 17, 1028-1034, doi:10.1074/mcp.TIR117.000518 (2018).

5 Hughes, C. S. et al. Ultrasensitive proteome analysis using paramagnetic bead technology. Mol Syst Biol 10, 757, doi:10.15252/msb.20145625 (2014).

6 Hughes, C. S. et al. Single-pot, solid-phase-enhanced sample preparation for proteomics experiments. Nat Protoc 14, 68-85, doi:10.1038/s41596-018-0082-x (2019).

7 isobarQuant (https://github.com/protcode/isob), 〈https://github.com/protcode/isob> (

8 Cox, J. \& Mann, M. MaxQuant enables high peptide identification rates, individualized p.p.b.-range mass accuracies and proteome-wide protein quantification. Nat Biotechnol 26, 1367-1372, doi:10.1038/nbt.1511 (2008).

9 Olsen, J. V. et al. Global, in vivo, and site-specific phosphorylation dynamics in signaling networks. Cell 127, 635-648, doi:10.1016/j.cell.2006.09.026 (2006).

10 Savitski, M. M. et al. Tracking cancer drugs in living cells by thermal profiling of the proteome. Science 346, 1255784, doi:10.1126/science.1255784 (2014).

11 Ritz, C., Baty, F., Streibig, J. C. \& Gerhard, D. Dose-Response Analysis Using R. PLoS One 10, e0146021, doi:10.1371/journal.pone.0146021 (2015).

12 Benjamini, Y. \& Hochberg, Y. Controlling the False Discovery Rate: A Practical and Powerful Approach to Multiple Testing. Journal of the Royal Statistical Society. Series B (Methodological) 57, 289-300 (1995).

13 Huang, J. X. et al. High throughput discovery of functional protein modifications by Hotspot Thermal Profiling. Nature Methods, doi:10.1038/s41592-019-0499-3 (2019).

14 Becher, I. et al. Pervasive Protein Thermal Stability Variation during the Cell Cycle. Cell 173, 14951507 e1418, doi:10.1016/j.cell.2018.03.053 (2018). 
15 Tan, B. X. et al. Assessing the Efficacy of Mdm2/Mdm4-Inhibiting Stapled Peptides Using Cellular Thermal Shift Assays. Sci Rep 5, 12116, doi:10.1038/srep12116 (2015).

16 Zecha, J. et al. TMT Labeling for the Masses: A Robust and Cost-efficient, In-solution Labeling Approach. Mol Cell Proteomics 18, 1468-1478, doi:10.1074/mcp.TIR119.001385 (2019).

17 Li, Q. R., Ning, Z. B., Tang, J. S., Nie, S. \& Zeng, R. Effect of peptide-to-TiO2 beads ratio on phosphopeptide enrichment selectivity. J Proteome Res 8, 5375-5381, doi:10.1021/pr900659n (2009).

18 Smith, I. \& et al. Identification of phosphosites that alter protein thermal stability. (unpublished).

19 Murillo, J. R. et al. Automated phosphopeptide enrichment from minute quantities of frozen malignant melanoma tissue. PLoS One 13, e0208562, doi:10.1371/journal.pone.0208562 (2018).

20 Post, H. et al. Robust, Sensitive, and Automated Phosphopeptide Enrichment Optimized for Low Sample Amounts Applied to Primary Hippocampal Neurons. J Proteome Res 16, 728-737, doi:10.1021/acs.jproteome.6b00753 (2017).

21 Tan, C. S. H. et al. Thermal proximity coaggregation for system-wide profiling of protein complex dynamics in cells. Science 359, 1170-1177, doi:10.1126/science.aan0346 (2018). 